\title{
THE STRUCTURE OF INTERPRETIVE REVOLUTIONS
}

\section{ORIGINALISM'S PROMISE: A NATURAL LAW ACCOUNT OF THE AMERICAN CONSTITUTION. By} Lee J. Strang. * New York, NY: Cambridge University Press. 2019. Pp. xiv + 326. \$110 (hardcover); \$34.99 (paperback)

\section{A. Jeremy Telman ${ }^{1}$}

\section{INTRODUCTION}

According to Lee Strang, "[o]riginalism's promise is to make sense of our constitutional practice while, at the same time, painting it in its best light" (p. 2). Professor Strang's book thus strives both to persuade his readers that originalism is our law (p. 2) and that interpreting the Constitution in accordance with its original meaning promotes human flourishing (pp.1-2). The book encapsulates at least a decade of work and thought. Strang's book possesses impressive historical scope, intellectual range, and philosophical rigor. Strang hews a path that accommodates the various strains of originalism seemingly without sacrificing the principles of fixity and constraint that define mainstream originalism. $^{2}$

In Part II of this Essay, I summarize Strang's defense of originalism. Actually, Strang provides two independent but complementary defenses of originalism. The first, which he calls

* John W. Stoepler Professor of Law \& Values, University of Toledo College of Law.

1. Associate professor, Oklahoma City University School of Law; Dean's Visiting Scholar, Georgetown University Law Center. Thanks to Karen Koelemeyer for her editorial assistance. I thank Lee Strang for years of intellectual exchange and engagement. His writings never fail to impress me with their intellectual scope and rigor, and they thus stimulate my own thinking on the subject.

2. See Lawrence B. Solum, The Fixation Thesis: The Role of Historical Fact in Original Meaning, 91 NotRe DAME L. REV.1 (2015) [hereinafter Solum, Fixation Thesis]; Lawrence B. Solum, The Constraint Principle (draft as of Apr. 3, 2019), available at https://ssrn.com/abstract=2940215. 
the communication model, offers historical and prudential arguments. The second, which he calls the coordination model, sounds in Aristotelian virtue ethics and makes the normative case for originalism. Strang's book enters a crowded market, with recent intelligent and highly readable works on originalism by Eric Segall ${ }^{3}$ and Ilan Wurman. ${ }^{4}$ Strang's book is far denser than theirs and makes more significant demands on its readers. Nonetheless, the book demands careful attention as the most important systematic defense of originalism since McGinnis and Rappaport's Originalism and the Good Constitution. ${ }^{5}$

In Part III, I raise four objections to Strang's theory of originalism. First, while Strang's theory accounts for and accommodates many criticisms of originalist theory, his approach inadequately addresses two problems that pose special challenges to his version of originalism. The first such challenge is that while Strang recognizes that the Constitution's meaning is indeterminate, he insists that indeterminacy is rarely an impediment to the originalist goal of fixing the Constitution's meaning. The second challenge is the level of generality at which the Constitution's original meaning binds us. The second objection notes that Strang's theory assumes an order of operations for reasons he never articulates, privileging ideologically driven and outcome-determinative "closure rules." If one changes the order of operations, given the range of originalist views, one can use Strang's theory to defend or criticize nearly any constitutional decision on originalist grounds. Third, Strang achieves consensus among originalist theories by downplaying genuine differences among them. As a result, Strang makes contemporary originalism seem more coherent and unified than it actually is. At the same time, Strang treats the difference between originalism and non-originalism as a difference in kind when it can be better understood as a matter of degree. Finally, Strang presents a heavily majoritarian view of the Constitution, acknowledging no special role for courts to step in to address encroachments on fundamental constitutional rights or on constitutional protections of minority groups.

3. ERIC J. SEgALL, ORIGINALISM AS FAITH (2018)

4. ILAN WURMan, A DebT Against the Living: AN Introduction to ORIGINALISM (2017)

5. JOHN O. MCGINNIS \& MICHAEL B. RAPPAPORT, ORIGINALISM AND THE GOOD CONSTITUTION (2013) [hereinafter MCGINNIS \& RAPPAPORT, GOOD CONSTITUTION]. 
In Part IV, I discuss Strang's learned, careful, theoretically sophisticated, and well-informed work as evidence that, unbeknownst to its practitioners, the originalist paradigm is in crisis. As the subject matter of interpretive theories raises new challenges to those theories, they become increasingly complex in order to accommodate the theories to the data. Eventually, the theories collapse under the weight of their own appendages. Out of the wreckage, new theories arise that provide more satisfying answers to the primary questions the theories aim to address. The very complexity and sophistication of contemporary academic originalism propels it away from the primary goal of the originalist movement, judicial restraint, and away from popular originalism, which exemplifies a popular constitutionalism to which books like Strang's cannot appeal. Part V briefly concludes with a few paragraphs describing a new post-originalist paradigm.

Despite my reservations about Strang's approach, I admire the intellectual rigor and good intentions that he brings to his project. Strang's fellow travelers on the originalist thoroughfare will find much truth (or ammunition) in his characterizations of our constitutional history. Strang's work provides ample fodder for debate both within and outside of the originalist camp. Wherever one happens to sit on the spectrum from originalism to non-originalism, one can benefit from Strang's account of constitutional history and his singular contributions to the theory of constitutional interpretation.

\section{ORIGINALISM'S PROMISE AND STRANG'S COMPROMISES}

In this Part, I aim to give a fair summary of Strang's argument. The task is daunting. Strang's book is very carefully reasoned, with many interlocking parts. In addition, this Part flags some of Strang's theoretical and factual claims with which I engage critically in more detail in Part III.

\section{A. ORIGINALISM AlL THE WAY DOWN}

The book's first chapter provides a history of originalism going back to the Founding. Here, although Strang offers some new evidence, for the most part, he treads familiar territory laid 
out in scholarship by Christopher Wolfe,${ }^{6}$ Jonathan O'Neill, ${ }^{7}$ and Howard Gillman. ${ }^{8}$ Strang presents the familiar narrative succinctly and well. Creating a coherent narrative history of originalism presents a two-fold challenge. The first challenge is historical. There was a not a great deal of constitutional adjudication in the nineteenth century, and the Justices were not always consistent or systematic in their approach. Strang acknowledges "notable errors" (p. 16), but those "blips" (p. 16 n.35) included landmark cases such as Dred Scott v. Sanford ${ }^{9}$ and The Legal Tender Cases. ${ }^{10}$ Second, as Strang notes, originalism is a "family of theories of constitutional interpretation" (p. 10), and the variety of originalist approaches makes it difficult to know what it means to say that Supreme Court opinions are or are not originalist. Nonetheless, Strang presents a narrative in which our constitutional history was largely consistent with originalism. ${ }^{11}$ His argument here parallels those of Will Baude and Stephen Sachs that "originalism is our law," although Baude and Sachs arrive at their position by means of a positivist turn. ${ }^{12}$ Strang, as we shall see, designates for positivism only a supporting role in a broader, natural-law account.

At some point, perhaps beginning in the late nineteenth century, or perhaps as late as the New Deal, originalism was displaced. According to Strang, these changes were caused by a combination of external stimuli and developments within the legal academy (p. 17). External factors included the desire of constitutional actors during the Progressive Era for a federal

6. Christopher Wolfe, THE Rise OF MODERn Judicial REVIEW: From CONSTITUTIONAL INTERPRETATION TO JUDGE-MADE LAW (1986).

7. JOHNATHAN O'NEILL, ORIGINALISM IN AMERICAN LAW AND POLITICS: A CONSTITUTIONAL HisTORY (2005).

8. Howard Gillman, The Collapse of Constitutional Originalism and the Rise of the Notion of the "Living Constitution" in the Course of American State-Building, 11 STUD. AM. POL. DEV. 191 (1997).

9. 60 U.S. (19 How.) 393 (1856).

10. 79 U.S. (12 Wall.) 457 (1870).

11. Following the vast majority of historians and legal scholars who have written about the early Supreme Court, I disagree with Strang's account. See D. A. Jeremy Telman, John Marshall's Constitution: Second-Order Ipse Dixit Reasoning in Constitutional Adjudication, 24 LEWIS \& CLARK L. REV. (forthcoming 2020) [hereinafter Telman, John Marshall's Constitution]; D. A. Jeremy Telman, Originalism and SecondOrder Ipse Dixit Reasoning in Chisholm v. Georgia, 67 CLEV. ST. L. REV. 559 (2019) [hereinafter Telman, Chisholm].

12. See William Baude, Is Originalism Our Law?, 115 COLUM. L. REV. 2349 (2015); Stephen E. Sachs, Originalism as a Theory of Legal Change, 38 HARV. J.L. \& PUB. POL'Y 817 (2015). 
government with more expansive powers and post-Darwinian scientism that pervaded society generally and also reached into the Langdellian legal academy (p. 19). That academy eventually succumbed to legal realism, which undermined belief in legal determinacy (p. 17).

From the New Deal to the 1960s, according to Strang, "originalism was almost entirely eclipsed" (p. 21), until scholars like Robert Bork and Raoul Berger responded with firstgeneration originalist intentionalism (pp. 23-25). However, this early version of originalism seemed to have been completely demolished by its critics in the 1980s. ${ }^{13}$ Five originalist responses to the demolition of intentionalism undergird Strang's version of originalism. First, originalism switched its focus, or at least its rhetoric, from original intention to original meaning. Second, originalists acknowledged that originalist interpretation has to be supplemented with construction. Third, many originalists reconciled themselves to accepting at least some non-originalist precedent. Fourth, originalists acknowledged that constitutional interpretation entails the exercise of discretion. Fifth, originalists offered various normative justifications for their approach (pp. 26-27).

Strang's originalism draws strength from its surface reasonableness. Strang nimbly accommodates seemingly contradictory impulses. Strang finds that the original intent, original meaning, and original methods approaches to originalism are not "substantively distinct" (p. 30). He embraces constitutional construction (p. 33) and non-originalist precedent when doing so "is important for the common good" (p. 34). Strang's Goldilocks approach to originalism risks rendering it a rather insipid theoretical porridge. Eric Segall, an outspoken critic of originalism, focuses on the middle three of Strang's five moves and contends that originalism is now no different from the nonoriginalist legal realism it opposes. Originalism, for Segall, is a form of rhetorical posturing, in which declarations of adherence to originalism communicate little more than allegiance to a libertarian conservative political faith. ${ }^{14}$ Strang's project avoids Segall's criticisms through rigorous cabining of uncertainty, construction, and judicial discretion. The success of Strang's

13. See Randy E. Barnett, An Originalism for Nonoriginalists, 45 LOY. L. REV. 611, 611-13 (1999).

14. SEGALL, supra note 3. 
project turns on the persuasiveness of his account of our constitutional history in Chapters $1-3$, and the attractiveness of the normative justification that he provides for originalism in Chapter 4, which is rooted in Aristotelian virtue ethics.

\section{B. COMMUniCATION, DEFERENCE, AND PRECEDENT}

Strang's second chapter introduces his constitutional communication model of originalism. His first step in elucidating this model consists of an argument linking original meaning, original intentions, and original methods. The text means what the Framers intended it to mean, and they understood that it would be interpreted according to original methods (pp. 44-47). Strang thus elegantly synthesizes the leading strains of originalist theory from the 1960 s to the present.

Strang elaborates his communication theory through what he calls a "focal case," which is a sort of ideal-typical reconstruction of the communicative act entailed in constitution writing (pp. 4850). Focal case interpretation involves understanding legislative acts as intended to overcome coordination problems and secure the common good. The goal of the interpreter should be to ascertain the intentions of the Framers and Ratifiers and thus to understand the meaning of the constitutional text (p. 49). That is, we should read the Constitution as an attempt to communicate binding legal norms, and the goal of interpretation should be the discovery and application of those legal norms.

Strang next tackles the problem of constitutional construction, which poses special challenges for contemporary originalism. The New Originalism, which focuses on original meaning rather than on intentions, has long recognized that original meaning "runs out" 15 and that constitutional decisionmakers thus operate in a construction zone in which original meaning constrains discretion to a lesser degree and may not constrain it at all. ${ }^{16}$ Original methods originalists reject this view, shrinking the construction zone to insignificance by exiling

15. See, e.g., Randy E. Barnett, Interpretation and Construction, 34 HARV. J.L. \& PUB. POL'Y 65, 69 (2011); Lawrence B. Solum, Semantic Originalism 19 (Univ. of Ill. Coll. of Law Ill. Pub. Law \& Legal Theory Research, Paper Series No. 07-24, 2008), https://ssrn.com/abstract=1120244.

16. Keith E. Whittington, Constructing a New American Constitution, 27 ConsT. COMM. 119, 123 (2010). I have argued elsewhere that original meaning runs out before originalist interpretation begins. D. A. Jeremy Telman, All That Is Liquidated Melts Into Air: Five Meta-Interpretive Issues, 24 BARRY L. REV. 1, 4 (2019). 
construction from the original interpretive toolkit. ${ }^{17}$ Here as elsewhere, Strang carves out a middle position, tending towards the more conservative position, acknowledging some, limited indeterminacy in the constitutional text (p. 66), but arguing that only the political branches - rather than courts - should engage in constitutional construction (p. 84). Most constitutional questions, Strang contends, have answers that we can discover through original methods, and the constitutional allocation of powers gives priority to the political branches' determinations of such original meaning (pp. 83-90). Strang thus leaves little to be worked out through constitutional construction, and such construction as must take place should be undertaken by the political branches, to which courts ought to defer. Whether Strang's positions in this area can be reconciled with his emphasis on the limited nature of federal legislative power (p. 71) and with the courts' institutional competence to enforce the Equal Protection Clause are taken up in Part III.D.

Strang proceeds to the subject of non-originalist precedent, another topic that has divided originalists. ${ }^{18}$ Strang positions himself among those who accept a limited role for non-originalist precedent (p. 103). He first defines originalist precedent as that involving a good faith attempt to discover and apply the Constitution's original meaning (pp. 92-97). His attempt to define good faith raises questions about levels of generality addressed in Part III.B., infra. For example, he points to Justice Douglas' invocation of "penumbras" in Griswold v. Connecticut, as an instance of non-originalist precedent (p. 96 n.221). However, it is far from clear that Douglas' penumbral approach was not a good faith attempt to give effect to original constitutional principles. Originalists have defended Griswold based on the Ninth

17. See MCGINNIS \& RAPPAPORT, GOOD CONSTITUTION, supra note 5, at 139-53; John O. McGinnis \& Michael B. Rappaport, Original Methods Originalism: A New Theory of Interpretation and the Case Against Construction, 103 Nw. U. L. REV. 751, 773 (2009) [hereinafter McGinnis \& Rappaport, Original Methods Originalism].

18. Some originalists reject all reliance on non-originalist precedent. See Gary Lawson, Mostly Unconstitutional: The Case Against Precedent Revisited, 5 AVE MARIA L. REV. 1 (2007); Michael Stokes Paulsen, The Intrinsically Corrupting Influence of Precedent, 22 CONST. COMM. 289 (2005). Others are willing to accommodate some nonoriginalist precedent. See MCGINNIS \& RAPPAPORT, GOOD CONSTITUTION, supra note 5, at 175; Kurt T. Lash, Originalism, Popular Sovereignty, and Reverse Stare Decisis, 93 VA. L. REV. 1437, 1442 (2007); Antonin Scalia, Originalism: The Lesser Evil, 57 U. CIN. L. REV. 849,861 (1989). 
Amendment ${ }^{19}$ and the Fourteenth Amendment's Privileges or Immunities Clause. ${ }^{20}$

Strang then takes up the challenge of explaining why originalism entails adherence to some non-originalist precedent. Here, Strang delves into far more historical material than he does in connection with his other claims, resulting in a far more persuasive defense of this position. Strang maintains that originalism must entail adherence to precedent because the original methods at the time of the Framing encompassed stare decisis (pp. 104-126). Strang endorses the embrace of nonoriginalist precedent in relatively limited circumstances. Stare decisis should bind courts only when: (1) the deviation from original meaning is slight; (2) rule of law values support abiding by precedent; and (3) the precedent, aside from being nonoriginalist, is just (pp. 126-133). His approach to precedent seems very close to that of McGinnis and Rappaport. ${ }^{21}$ As with Strang's similarities with Baude and Sachs, Strang arrives via virtue ethics at essentially the same conclusion at which McGinnis and Rappaport arrive through consequentialism.

Strang illustrates his theory with a discussion of two arguably non-originalist precedents. He argues that, although most originalists view Brown v. Board of Education as a non-originalist decision, it did not stray far from original meaning (pp. 132-134). Moreover, Strang contends, pervasive reliance on Brown supports rule of law interests in the maintenance of the Brown precedent (p. 135). Finally, Strang thinks Brown was a just decision that ought to be followed even if it cannot be reconciled with at least some versions of originalism (pp. 132-133). Roe v. Wade $^{22}$ does not fare as well. Strang finds Roe irredeemably nonoriginalist (p. 135). He does not think departure from Roe would upset settled expectations or undermine the rule of law (p. 136), nor does he think that justice requires adherence to Roe (pp. 136137). I raise questions as to the assumptions underlying Strang's analysis of Brown and Roe in Part III.D., infra.

19. Eugene McCarthy, In Defense of Griswold v. Connecticut: Privacy, Originalism, and the Iceberg Theory of Omission, 54 WILLAMETTE L. REV. 335 (2018).

20. Michael B. Rappaport, Is Griswold v. Connecticut Consistent with the Original Meaning?, L. \& LIBERTY BLOG (July 17, 2014), https://www.lawliberty.org/2014/07/17/isgriswold-v-connecticut-consistent-with-the-original-meaning/.

21. MCGINNIS \& RAPPAPORT, GOOD CONSTITUTION, supra note 5, at 175-96.

22. 410 U.S. 113 (1973). 
Having laid out his communicative model and his deference theory of originalism, Strang explains how originalism benefits from virtue ethics. His theory of virtue ethics has two components. First, it requires judges who possess the qualities of theoretical wisdom, practical wisdom, justice-as-lawfulness, temperance, and fortitude (pp. 144-147). Second, Strang argues that virtue ethics make originalism both more descriptively cohesive and more normatively attractive (pp. 148-157). He describes virtue ethics as a brake on judicial discretion, as it serves to cabin legal indeterminacy while preserving originalism's core commitments. It thus also restricts judicial whim (p. 157).

\section{ORIGINALISM'S FIT AND FLEXIBILITY}

In Chapter 3, Strang argues that originalism best describes our constitutional practice. Strang connects his argument to those of other originalists who have treated the "fit" between the Constitution's original meaning and our constitutional practice as evidence that originalism is our law (p. 162). The chapter first addresses the connection between originalism and the fact that the Constitution is written (pp. 166-176). It next presents Supreme Court opinions as consistent with originalism (pp. 176194). Finally, Strang presents originalism as having the capacity to accommodate social and constitutional change (pp. 195-220).

The importance of the fact that the Constitution is a written document is evidenced, according to Strang, by the Constitution's use of "indexicals" (pp. 167-168). Repeatedly, the text refers to itself as "[t]his Constitution," signaling the Framers' understanding that the original meaning of the document would bind future generations (pp. 168-169). However, this argument may prove too much. Non-originalists agree that, where the Constitution has a clear meaning, the proper object of constitutional interpretation is the United States Constitution rather than some other constitution or some other document. The question is not whether we interpret "this Constitution," but how we go about doing so.

The outrage of the first generation of originalists poses a problem for Strang and others who claim that originalism is our law. ${ }^{23}$ Early originalists clearly understood themselves as

23. See, e.g., RAOUL BERGER, GOVERNMENT BY JUDICIARY: THE TRANSFORMATION OF THE FOURTEENTH AMENDMENT (1977); ROBERT H. BORK, THE 
critiquing Supreme Court practice, and non-originalists, as Strang notes, consider originalism a reform movement in large part because originalism first presented itself as a movement for reform in the practice of constitutional interpretation (p. 164). Even contemporary originalists claim that there is a need to "restore" the Constitution to its original meaning. ${ }^{24}$ There would be no need for restoration, from an originalist perspective, if originalism had always been our law.

Strang overcomes these objections by, once again, assuming an intermediate position between originalists, who reject our tradition of non-originalist precedent, and non-originalists, who regard common-law constitutionalism as the essence of our constitutional tradition. Strang stresses the ability of originalism to definitively settle constitutional questions. Strang provides a list of issues that he thinks the Constitution has resolved (p. 195). However, one might object that his list includes issues, such as federal protections for abortion and whether regulation of healthcare constitutes a lawful regulation of commerce, that continue to present live controversies both as to lawfulness and as to original meaning. Strang then reprises his arguments in favor of the preservation of some non-originalist precedent (pp. 197205). Finally, and somewhat at odds with his dismissal of Jack Balkin's "thin" concept of original meaning (p. 202 n.189), Strang appropriates Balkin's central distinction among constitutional rules, standards, and principles (pp. 209-214). ${ }^{25}$

While Strang follow's Balkin's categorization of the Constitution's language, he immediately veers away from Balkin's deconstruction of the binary opposition between originalism and living constitutionalism. Instead, Strang revisits his earlier discussions of constitutional construction and non-originalist precedent to reinforce his conclusions that: (1) the meaning of the Constitution is largely determinate (pp. 215-216); and (2) where indeterminacy exists, the political branches rather than the courts have both the institutional competence and the constitutional authority to undertake constitutional construction (pp. 217-218).

TEMPTING OF AMERICA: THE PoliticAl SEduction OF THE LAW (1990).

24. See, e.g., RANDY E. BARnett, RESTORING the Lost CONSTITUTION: THE PRESUMPTION OF LiberTy (rev. ed. 2014); MYron MAGNET, ClarenCE THOMAS AND THE LOST CONSTITUTION (2019).

25. See JACK M. BALKIn, Living Originalism 6-16 (2011). 


\section{THE NORMATIVE COMPONENT: LAW AS COORDINATION}

In the book's fourth chapter, Strang presents his coordination model, which serves as both a normative supplement to his communication model, and as a stand-alone, normative defense of originalism (p. 220). That is, if one is convinced by the communication model, one does not need the coordination model; if one is not convinced by the communication model, one may still accept the coordination model.

Strang describes his normative defense of originalism as "thin": his model generally does not endorse particular resolutions of constitutional controversies; its central ends, human flourishing and the common good, are defined only in the most general terms; and if one does not agree that the function of the Constitution is to promote human flourishing, substitute some other goal, and the theory should work just as well (pp. 227-228). Strang's notion of human flourishing draws on natural law and Aristotelian virtue ethics (pp. 233-241). His notion of the common good comes down to justice, the rule of law, and the offices that effectuate those values through social coordination (pp. 241-278).

One of the many interesting components of Strang's approach is his marriage of natural law and positivism. These approaches are often seen as polar opposites, but Strang argues persuasively for the role of positive law within a natural law approach (pp. 266-268). His argument for a role for positive law follows from his equally interesting discussion favoring the role of authority, rather than consent, in social coordination (pp. 246265). The authority of positive law provides the critical lynchpin linking Strang's account of natural law to his defense of originalism. In Strang's view, the Constitution, as our original founding law, provides authoritative solutions to seemingly indeterminate problems, thus promoting human flourishing and the common good (pp. 278-307).

Strang is convinced that everyone must accept the coordination model, because it contains nothing to which one could reasonably object (p. 228). That may well be true, if only because Strang avoids giving any content to his theory's key objectives, "human flourishing" and "common good." His theory may succeed in convincing readers that the Constitution ought to be interpreted so as to promote human flourishing, but if that term is not defined, readers may find that Strang's theory provides 
relatively little guidance. In addition, Strang may encounter more resistance than he expects to his Aristotelian account of human nature, as both rational and animal (p. 233), and the fundamental virtues, which Strang describes as "both constitutive of human flourishing and instrumental to securing it" (pp. 236-238).

\section{THE SKEPTIC'S PERSPECTIVE}

In the first substantive footnote of his book, Strang writes: "The Constitution directly decides the substance of many important issues" (p. 1 n.2). Already, the word "directly" puts us on shaky ground. The Constitution clearly decides uncontroversial matters, like the requirement that the President must be thirty-five years of age upon taking office. ${ }^{26}$ The claim that the Constitution directly decides other substantive issues is problematic, because some form of mediation, which might be a legislative decision, an executive order, judicial interpretation or construction, or practice, mediates between the constitutional text and the resolution of the substantive issue. Moreover, the substance of many, if not most, important issues is never decided by the Constitution. Rather, fundamental constitutional questions reappear in different guises, seem resolved, only to recur after a generation or two. ${ }^{27}$

While recognizing that the Constitution's text often does not provide dispositive meaning, Strang insists that its meaning is accessible and that many tough constitutional riddles have been resolved. In order to agree with him, one must both accept his factual claims, which are often stated rather than argued for, and ignore his silences, through which Strang suppresses some of the most uncomfortable implications of his argument. Strang argues at length that originalism best describes our constitutional practice, but originalism, as he describes it, cannot be reconciled with our current law. His Constitution affords no special protections for fundamental rights (pp. 290-291), and it would eliminate substantive due process altogether (p. 289); it could accommodate Plessy's endorsement of "separate but equal" as a fulfillment of the Equal Protection Clause's promise (p. 21); and it revives the Lochner era's approach to commerce powers (pp. 16, 101-103). Many other constitutional doctrines would be open

26. U.S. CONST. art. II, $\S 1$, cl. 5; see BALKIN, supra note 25, at 6 .

27. See Telman, supra note 16. 
to challenge. Despite his book's length, Strang says little about the non-delegation doctrine and the administrative state, the constitutional allocation of war powers, standing doctrine, and the post-Hans ${ }^{28}$ reading of the Eleventh Amendment to prohibit actions in federal court by citizens against their own states.

Strang's inconsistencies threaten to deprive "originalism" of any content beyond an expression of approbation of disapprobation of certain Supreme Court opinions and doctrines. Strang heralds five-to-four decisions like Heller, ${ }^{29}$ which recognized for the first time a constitutionally protected individual right to bear arms, and National Federation of Independent Business $v$. Sebelius, ${ }^{30}$ which found that the Affordable Care Act exceeded Congress's Commerce Clause powers, as returning us to the Constitution's original meaning (pp. 190, 195). Both of these opinions failed to defer to Congress, which, according to Strang, is far more qualified than the Court to engage in social ordering through constitutional interpretation so as to promote human flourishing and the common good (p. 87). Justice Stevens, who wrote the originalist dissent in Heller, called it "unquestionably the most clearly incorrect decision that the Supreme Court announced during my tenure on the bench." 31

Strang mostly insists on a Jeffersonian republicanism that would read the Necessary and Proper Clause and implied congressional powers out of the Constitution. Much rides on his "closure rule," which treats the Tenth Amendment as a substantive provision limiting Congress to the exercise of enumerated powers (p. 55). He seems to treat Article I's enumeration as exclusive and mentions neither implied powers nor the Necessary and Proper Clause (p. 71). However, he also accords to Congress breathtaking powers to determine what promotes the common good (p. 87). The notion that Congress could exercise a general power to determine the common good would horrify the staunchest federalists in the tradition of Alexander Hamilton and John Marshall. Jefferson, upon reading such a description of congressional power, would have boarded

28. Hans v. Louisiana, 134 U.S. 1 (1890).

29. District of Columbia v. Heller, 554 U.S. 570 (2008).

30. 567 U.S. 519 (2012)

31. See John Paul Stevens, The Supreme Court's Worst Decision of My Tenure, ATLANTIC MONTHLY (May 14, 2019), https://www.theatlantic.com/ideas/archive/2019/05 /john-paul-stevens-court-failed-gun-control/587272/. 
the next available ship heading towards Revolutionary France.

\section{A. INDETERMINACY AND THE LEVELS OF GENERALITY CHALLENGE}

When Strang reviews early criticisms of originalism, he mentions, but never really addresses, Paul Brest's vital elaboration of what has become known as the level of generality problem (pp. 25-26). Brest's argument undermines what Larry Solum called the Fixation Principle - that is, the notion that the Constitution's meaning was fixed at the time of its adoption. ${ }^{32}$ Originalism does not tell us at what level the Constitution binds us. ${ }^{33}$ To take one of Brest's examples, originalism cannot tell us whether the Constitution's prohibition of "cruel and unusual punishment" applied only to sanctions that the Framers considered cruel or to the concept of cruelty more generally. ${ }^{34}$ Does originalism require an inquiry into what punishments were considered cruel in the eighteenth century or a more general consideration of what it means to be cruel?

Early originalism provided no solution to the problem of levels of generality, and as Strang acknowledges, New Originalism conceded that many constitutional decisions are made in the construction zone where original meaning does not bind constitutional decisionmakers (p. 32). Uncomfortable with the level of judicial discretion permitted under New Originalism, Strang follows John McGinnis and Michael Rappaport in trying to cabin underdeterminate original meaning through original methods (pp. 227-228). But an enumeration of the Framers' interpretive methods only exacerbates indeterminacy. As I have argued elsewhere, original methods entailed a non-hierarchical methodological pluralism that does not yield the legal determinacy that Strang seeks. ${ }^{35}$ The Framers deployed numerous interpretive strategies and did not privilege any particular mode of interpretation. Strang cites Blackstone, who provided the model for such methodological pluralism, but he treats Blackstone as evidence of originalism in the founding generation.

32. Solum, Fixation Thesis, supra note 2, at 1

33. Paul Brest, The Misconceived Quest for Original Understanding, 60 B.U. L. REV. 204, $221(1980)$

34. Id. at 220-21.

35. Telman, John Marshall's Constitution, supra note 11; Telman, Chisholm, supra note 11 . 
However, as Strang notes, Blackstone embraced textualism, contextualism, pragmatism, and teleology (pp. 12-13). The courts of the Early Republic supplemented those interpretive strategies with intentionalism, structuralism, and appeals to morals, historical and legal precedent, logic, and common sense, with no one method trumping the others. ${ }^{36}$

That pluralism was clear in the pre-Marshall Court, where each Justice rendered his opinion seriatim. ${ }^{37}$ The eighteenthcentury Justices neither attempted nor achieved resolution of constitutional controversies; they arrived at no consensus about constitutional meaning beyond narrow agreement on the disposition of the case. John Marshall's introduction of the opinion of the Court and his discouragement of dissent provides the appearance of clear resolution of constitutional issues, but his opinions were not treated with uniform reverence at the time. Thomas Jefferson decried Marshall's decision in $\mathrm{McCulloch}^{38}$ as reducing the Constitution to a "mere thing of wax in the hands of the judiciary, which they may twist and shape into any form they please." ${ }^{39}$ Nor does Marshall's dismissive attitude towards counterarguments and his insistence on unanimity accord with Strang's description of what it means to apply original meaning in good faith (p. 95).

Throughout much of the book, Strang's notion of originalism seems closest to original intended application originalism. $\mathrm{He}$ treats Brown as "non-originalist" because schools were segregated at the time the Fourteenth Amendment was adopted (pp. 132-133)..$^{40} \mathrm{He}$ thinks the Legal Tender cases were "nonoriginalist," because the original intended application of Congress's power to "coin money" applied to coins and not to paper money (p. 128).

Suddenly, two thirds of the way into the book, Strang

36. Telman, John Marshall's Constitution, supra note 11, at 17.

37. Telman, Chisholm, supra note 11, at 595-97.

38. McCulloch v. Maryland, 17 U.S. (4 Wheat.) 316 (1819).

39. Letter from Thomas Jefferson to Judge Spencer Roane (Sept. 6, 1819), in 10 THE Writings of THOMAS JeFFERSON 140, 141 (Paul Leicester Ford ed., 1899). Virginia Supreme Court Justice Spencer Roane's forceful criticisms of $\mathrm{McC}$ Culloch are reprinted in JOHN MARSHALL'S DEFENSE OF MCCULLOCH V. MARYLAND 107-54 (Gerald Gunther ed., 1969).

40. To be fair, Strang assumes for the sake of argument, that Brown is non-originalist. However, the only grounds he provides for its non-originalism is the existence of segregated schools at the time of the Fourteenth Amendment's adoption. 
renounces original intended applications originalism (p. 214) and takes up the issue of levels of generality (pp. 209-214). He fully accepts Jack Balkin's distinction between the Constitution's rules, standards, and principles but somehow misses Balkin's point. Once one accepts that the Constitution articulates guidelines and principles, one can argue, as Balkin does, that originalism supports a constitutional right to abortion; ${ }^{41}$ that the Commerce Clause empowers Congress to provide national solutions to problems that the states cannot address; ${ }^{42}$ and that the Equal Protection Clause embodies an anti-discrimination principle with broad application. ${ }^{43}$ Strang insists on determinate meaning through the imposition of ideologically tinged closure rules (discussed in the next section) and distinctions between originalist and non-originalist precedent that would only make sense if originalism itself were determinate. However, as Strang's tardy acknowledgement of the levels of generality problem illustrates, it is not.

\section{B. ORDER OF OPERATION PROBLEMS}

Strang seeks to constrain constitutional construction, clearly regarding it as a threat to legal determinacy. Relying on John McGinnis and Michael Rappaport's original methods theory and his "closure rules," Strang claims that the Constitution's original meaning, even when "epistemically" underdeterminate, is "metaphysically determinate" (p. 73). However, McGinnis and Rappaport cannot provide a firm foundation for Strang's theory of construction for two reasons. First, McGinnis and Rappaport reject construction altogether. ${ }^{44}$ Second, originalists have subjected original methods originalism to searching criticisms. ${ }^{45}$

Strang identifies three limits on constitutional construction: interpretive "closure" rules limit indeterminacy; construction only occurs when constitutional meaning is indeterminate; and within the construction zone courts should defer to the political

41. See BALKIN, supra note 25, at 214-18.

42. See id. at 138-77.

43. See id. at 220-55.

44. See McGinnis \& Rappaport, Original Methods Originalism, supra note 17.

45. See Kurt T. Lash, Originalism All the Way Down?, 30 CONST. COMM. 149 (2015). William Baude and Stephen Sachs, who embrace a version of original methods originalism, think construction was an original method. See Baude, supra note 12, at 2357-58; William Baude \& Stephen E. Sachs, The Law of Interpretation, 130 HARV. L. REV. 1079, 1086, 1128 (2017). 
branches (p. 64). Strang then introduces three closure rules: (1) in cases of uncertainty, courts should construe the Constitution based on the best available evidence (p. 66); (2) arguments in favor of federal power bear the burden of proof and lose if the Constitution's meaning is ultimately indeterminate (p. 70); and (3) arguments limiting the powers of state governments bear the burden of proof, with the same consequence in cases of indeterminacy (p. 72). The first rule is uncontroversial; the second and third rules reflect Strang's political preferences more than they do the Constitution's determinate meaning. Strang neither includes a closure rule in favor of individual rights nor explains why no such rule is applicable. Strang's silence is striking in light of Randy Barnett's extensive and influential normative arguments for originalism as the best guarantor of individual liberties. ${ }^{46}$

These "closure" rules assume determinacy in realms where many scholars see indeterminacy. Strang places great weight on statements emphasizing the enumeration of congressional powers in Article I, Section 8 (p. 71), ignoring or relegating to footnotes recent historical (if not originalist) scholarship suggesting that Congress's Commerce Clause powers, as supplemented by the Necessary and Proper Clause[s], and inherent and implied powers, permit Congress to exercise something very similar to the general police powers supposedly reserved to the states. ${ }^{47}$ As to the states, Supreme Court Justices in the Early Republic either rejected their sovereignty outright ${ }^{48}$ or limited that sovereignty with great energy whenever state powers encroached on the exercise of even implied federal powers. ${ }^{49}$ Strang deploys as outcome-determinative interpretive principles constructs that are better characterized as political or ideological commitments.

Even if these closure rules were somehow ordained through original methods, rather than through Strang's political predilections, their resolution of any constitutional dispute would turn on the order in which they were deployed. In the interests of

46. BARNETT, supra note 24

47. See, e.g., John Mikhail, The Necessary and Proper Clauses, 102 GEO. L.J. 1045 (2014); Richard Primus, The Limits of Enumeration, 124 YALE L.J. 576 (2014); Richard Primus, Why Enumeration Matters, 115 MICH. L. REV. 1 (2016); Robert J. Reinstein, The Aggregate and Implied Powers of the United States, 69 AM. U. L. REV. 3 (2019).

48. See Chisholm v. Georgia, 2 U.S. (2 Dall.) 419, 457 (1793) (opinion of Wilson, J.); $i d$. at 479 (opinion of Jay, C.J.); id. at 468 (opinion of Cushing, J.).

49. See McCulloch v. Maryland, 17 U.S. (4 Wheat.) 316, 430 (1819). 
brevity, I will present only two examples.

To illustrate his closure rule that operates as a presumption against federal power, Strang presents a stylized version of the challenge to Obamacare. ${ }^{50}$ In Strang's telling, the government bore the burden in that case of providing legal evidence that the Affordable Care Act was "justified by reference to an enumerated power" (p. 71). Strang's formulation is misleading. Unless Strang rejects Chief Justice Marshall's decision in McCulloch and all subsequent cases relying on that opinion, Congress can act not only pursuant to its enumerated powers but also pursuant to implied powers. It was in making precisely this point that Marshall wrote his famous dictum that a Constitution cannot "partake of the prolixity of a legal code." 51 Strang's conclusion results not from that line of precedent but from his second closure rule, the presumption against federal power. But how would his discussion proceed if he began with his third limitation on construction: deference to legislatures? Arguments for and against the Affordable Care Act were not in equipoise when they arrived at the Supreme Court. Congress had already determined that the Act was a constitutional exercise of its Commerce Clause powers. According to Strang's third limiting principle, the Court ought to have deferred to that determination. Construction having already occurred, the closure rules ought not to apply, and the Court should have upheld Congress's determination that it could enact the Affordable Care Act pursuant to its Commerce Clause powers.

The same analysis applies with even more force to Second Amendment challenges to the regulation of firearms. As the fiveto-four decisions in Heller ${ }^{52}$ and McDonald ${ }^{53}$ make clear, the constitutional arguments were closely balanced, but hundreds, if not thousands, of state and local bodies had passed gun control legislation in the belief that the Second Amendment had nothing to say about the individual right to bear arms. That determination by the political branches ought to have weighted the scales in favor of gun regulation. ${ }^{54}$ In the case of state and local gun control

50. Nat'l Fed'n of Indep. Bus. v. Sebelius, 567 U.S. 519 (2012).

51. McCulloch, 17 U.S. (4 Wheat.) at 406-07.

52. District of Columbia v. Heller, 554 U.S. 570 (2008).

53. McDonald v. City of Chicago, 561 U.S. 742 (2010).

54. Strang provides only a brief discussion of the Second Amendment. He seems to think the question of its intended scope has been answered in scholarship written since the 1980s that advances the position that the Second Amendment protects an individual right 
laws, the presumption against federal power again would tip the balance in favor of the power of local authorities to regulate guns in accordance with their own notions of social ordering in the interests of human flourishing and the common good. If we change the order of operations, Strang should denounce Heller as judicial overreach, a constitutional error compounded in McDonald by its expansion of the "non-originalist" precedent of incorporation through substantive due process. ${ }^{55}$

\section{THE DANGERS OF FORCED CONSENSUS}

Strang masterfully navigates the different strains of originalism without picking sides and attempts to reconcile differences through compromise positions. As a result, he renders originalism nearly impervious to criticisms but also indistinguishable from various forms of "non-originalism." Like non-originalists, Strang accepts the binding nature of nonoriginalist precedent (pp. 91-142), believes that the Constitution lays down not only rules but also more flexible standards and principles (pp. 211-14), acknowledges that the original meaning of the constitutional text is sometimes indeterminate (and Strang hazards no guesses as to the extent of the indeterminacy) (p. 195), and recognizes that constitutional decisionmakers must consult both practical considerations, like "[r]ule of [1]aw" values (pp. 128-140) and personal ethics (pp. 142-157) in order to resolve hard cases. As a result, Strang, like non-originalists, concedes that judges must exercise discretion (p. 37).

Strang follows Larry Solum in characterizing originalism's "core" as the view that "the Constitution's meaning was fixed at the time of ratification and that the Constitution's fixed meaning contributes to constitutional meaning" (p. 11, emphasis added), but very few non-originalists would dispute the claim that the Constitution contributes to constitutional meaning. Strang attempts to limit the indeterminacy of the constitutional text by embracing Larry Solum's concept of "contextual enrichment," as an aid to uncovering constitutional meaning (p. 28). Strang describes contextual enrichment as "complex," "capacious," and "open-ended" (pp. 28-29). Nonetheless, Strang thinks that upon

to bear arms. Strang describes this scholarship as making "determinate what was once epistemically underdeterminate" (p. 83). Strang's conclusion on this matter seems premature, given that four Justices rejected that scholarship in their Heller dissents.

55. See McDonald, 561 U.S. at 791 (Scalia, J., concurring). 
review of the historical record, "it is often clear" that constitutional words or phrases "had a commonly accepted, though unarticulated public meaning" (p. 29). I find that conclusion hard to reconcile with the technique of contextual enrichment if practiced by a researcher free from confirmation bias. Strang somehow manages to be both dogmatic and hard to pin down.

Throughout his book, Strang declares Supreme Court opinions to be originalist or non-originalist without explaining the criteria that justify the nomenclature and without acknowledging disputes challenging his conclusions. For example, he calls the opinions of five Justices, including John Jay and James Wilson, in Chisholm v. Georgia "incorrect," and claims that the Eleventh Amendment "restored the correct interpretation of Article III" (p. 173). He cites to Sturges v. Crowninshield ${ }^{56}$ and Ogden v. Saunders ${ }^{57}$ as "evidence of how the Constitution's original meaning is not in tension" (pp. 191-192), but he fails to mention that John Marshall wrote his sole dissent in a constitutional case in Ogden v. Saunders. In that dissent, Marshall specifically scolded his fellow Justices for failing to give effect to the clear intent of the Framers as memorialized in the Constitution's text. ${ }^{58}$ The confidence with which Professor Strang passes judgment on these decisions is at odds with his frank admission that "[i]t is not possible to identify specific portions of the Constitution's text for which there was underdetermined original meaning without significant historical research, which is beyond the scope of this book" (p. 65).

Uncertainty about the meaning and content of originalism raises difficulties for Strang's third chapter, in which he claims that originalism explains our existing constitutional practice. Does Raoul Berger's originalist intentionalism best correspond to our practice or does Randy Barnett's libertarian textualism? Did generations of Americans adhere to the complex and sophisticated versions of originalism espoused by contemporary originalists? Did John Marshall anticipate Gricean linguistics so that he could practice originalism à la Solum? Did Justice Taney subscribe to the consequentialism that underpins McGinnis and Rappaport's original methods originalism, or was he more of a

56. 17 U.S. (4 Wheat.) 122 (1819).

57. 25 U.S. (12 Wheat.) 213 (1827).

58. Id. at 332 (Marshall, C.J., dissenting). 
legal positivist who followed Baude and Sachs's original law originalism? Did Justice Holmes believe one should reject all nonoriginalist precedent, as Gary Larson and Michael Stokes Paulsen maintain, or did he agree with Strang and others who think one should abide by some non-originalist precedent when doing so furthers the common good? Is our tradition one of strict construction, as the Senate Judiciary Committee insists every time it questions a judicial nominee, or has Jack Balkin better captured the tradition as one of fidelity to text and principle, ${ }^{59}$ an approach that marries originalism and living constitutionalism into living originalism?

While Strang presents a false consensus among originalists, his version of non-originalism borders on parody. Towards the end of his book, Strang purports to refute some non-originalist counter-arguments to his coordination account of originalism. Instead of citing to actual non-originalist arguments, Strang invents a non-originalist judge and then attributes to that judge positions that do not represent the best arguments that nonoriginalism has to offer (pp. 303-307). It is not as if originalists think the Constitution is binding while non-originalists think the Constitution is irrelevant. Rather, the two camps disagree as to how frequently original meaning runs out and about whether original meaning is always dispositive even when it is at odds with logic, common sense, and contemporary views of the common good. Strang's own discussion of why courts should abide by some non-originalist precedent is but one example of ways in which the difference between originalism and non-originalism is a matter of degree. Strang rarely discusses Article II in his book, and with good reason. The current scope of executive power in our constitutional order is very difficult to reconcile with the Framers' understanding of the role of the President. ${ }^{60}$ Michael Ramsey has gone so far as to argue that too much is at stake to allow executive power to be constrained by originalism. ${ }^{61}$

\section{RESTORING OUR LOST FOURTEENTH AMENDMENT}

In the introduction to his book (p. 3), Strang provides an

59. BALKIN, supra note 25, at 3-20.

60. See Julian Davis Mortenson, Article II Vests the Executive Power, Not the Royal Prerogative, 119 Colum. L. REv. 1169 (2019); Julian Davis Mortenson, The Executive Power Clause, 167 U. PA. L. REV. (forthcoming 2020).

61. See Michael D. Ramsey, Presidential Originalism?, 88 B.U. L. REV. 353 (2008). 
extended quotation that lays out the position that his descriptive chapters attempt to refute. Richard Fallon noted that "originalists candidly admit [that] originalist principles cannot explain or justify much of contemporary constitutional law." He further observed that "the public generally accepts the courts' nonoriginalist pronouncements as legitimate" ${ }^{62}$ and that originalists are not positivists but "carry [a] burden of normative justification." 63 Strang's attempt to refute Fallon's characterization of our law would be more persuasive if he did not ignore almost entirely the Fourteenth Amendment. More specifically, while Strang is willing to accept Brown v. Board of Education as a palliative non-originalist contribution to our law, he ignores the expansion of equal protection in other areas, and he rejects heightened scrutiny and substantive due process ( $\mathrm{p}$. 126), which is the mechanism whereby the Bill of Rights became applicable against the States. ${ }^{64}$ Even if one accepts the rest of Strang's descriptive case for originalism, it does not cover the vast realm of individual rights, to say nothing of executive power, as mentioned above.

Because Strang rarely addresses the protection of individual rights directly, my argument here relies in part on inference. His Constitution is a majoritarian Constitution, with the courts having almost no role in protecting either minority groups or fundamental rights from the majoritarian consensus as to what promotes human flourishing and the common good. Sure, judges get to exercise their "practical wisdom" in applying the original meaning of constitutional provisions to specific factual scenarios (p. 145), but their wisdom is subordinate to that of the majoritarian political branches, to which Strang insists they must defer (p. 84).

Strang's treatment touches on the future of equal protection and individual rights through his discussion of non-originalist precedent. In the interests of space, I will limit my critique of Strang's approach to his contrasting treatment of Brown and Roe.

As indicated above, Strang provides a three-step test for when courts should uphold non-originalist precedents (p. 126).

62. Richard H. Fallon, Jr., How to Choose a Constitutional Theory, 87 CALIF. L. REV. 535,547 (1999).

63. Id. at 548 .

64. See, e.g., Everson v. Bd. of Educ., 330 U.S. 1, 15 (1947); Gitlow v. New York, 268 U.S. 652, 666 (1925). 
Although Strang treats Brown as a non-originalist case throughout his book, he argues that its departure from originalism is "relatively minor" (p. 135). His criteria for so arguing seem arbitrary. Unlike Roe, which followed a line of Supreme Court precedents going back at least to Griswold, ${ }^{65}$ Brown rejected an existing Supreme Court case, Plessy v. Ferguson, ${ }^{66}$ and its ratio decidendi was based on policy, because the Court determined that the original meaning of the Equal Protection Clause was indeterminate. ${ }^{67}$ One can argue that the Brown Court could have reached the same result through a proper originalist analysis, which the Court did not undertake, as Strang does (p. 134), but the same has been said of Roe. ${ }^{68}$ As Strang notes (pp. 132-133), originalist scholarship at first overwhelmingly rejected Brown, and the most significant originalist scholarship supporting Brown was not written until forty years after it was decided (p. 133 n.423) $)^{69}$-and after the Court's swing to the Right, which coincided with the retreat in originalist theory from the doctrine of judicial restraint. ${ }^{70}$

Strang next argues that reversing Brown would undermine rule of law values because the case has been relied on and is imbedded in our law (p. 135). It is hard to imagine why Strang thinks that is so. He cites to laws such as the Civil Rights Act of 1964 that are consistent with Brown, but reversing Brown would not eliminate the Civil Rights Act, unless Strang also wants to reverse Heart of Atlanta ${ }^{71}$ and Katzenbach v. McClung. ${ }^{72}$ The Supreme Court gave up on enforcing Brown almost as soon as it

65. Griswold v. Connecticut, 381 U.S. 479 (1965).

66. Plessy v. Ferguson, 163 U.S. 537 (1896).

67. Brown v. Bd. of Educ., 347 U.S. 483, 492-93 (1954).

68. See, e.g., Anita L. Allen, The Proposed Equal Protection Fix for Abortion Law: Reflections on Citizenship, Gender, and the Constitution, 18 HARV. J.L. \& PUB. POL'Y 419 (1995) (endorsing arguments for abortion based on the Equal Protection Clause); Jack M. Balkin, Abortion and Original Meaning, 24 CONST. COMM. 291, 319-36 (2008) (arguing that the right to abortion is protected under the Equal Protection and Privileges or Immunities Clauses).

69. Citing Michael W. McConnell, Originalism and the Desegregation Decisions, 81 VA. L. REV. 947 (1995).

70. Keith E. Whittington, Originalism: A Critical Introduction, 82 FORDHAM L. REV. 375, 391 (2013).

71. See Heart of Atlanta Motel, Inc. v. United States, 379 U.S. 241 (1964) (upholding the constitutionality of the Civil Rights Act under the Commerce Clause).

72. See Katzenbach v. McClung, 379 U.S. 294 (1964) (upholding the constitutionality of the Civil Rights Act as applied to a barbecue restaurant based on the Commerce Clause and Wickard v. Filburn). 
started to have a meaningful effect on school desegregation. ${ }^{73}$ Today, many cities are committed to school desegregation, but in Parents Involved ${ }^{74}$ the Court cited to Brown in preventing local governments from combatting de facto segregation. ${ }^{75}$ If anything, overturning Brown would facilitate school desegregation and the justice interest that Strang cites in support of Brown, by removing federal barriers to local efforts to desegregate. Claims that Brown was a just decision must be measured in the light of de facto segregation overseen by a Supreme Court that would rather see segregated schools than tolerate the "injustice" of allowing Seattle and Louisville to determine that a few dozen white kids have to assist in school integration. ${ }^{76}$

Parents Involved should horrify Strang. In that case, a nonoriginalist precedent provided the basis for imposing federal law on localities. Worse still, that imposition of federal law came in the form of a slim Supreme Court majority imposing its understanding of the Equal Protection Clause on local legislative bodies. The people of Louisville and Seattle worked out a plan for their own public schools. Why should five Justices sitting in Washington, D.C., have the constitutional authority to dismantle those plans? Strang's case for the retention of the "nonoriginalist' Brown precedent is unconvincing.

No serious scholar should pretend either that the Constitution provides clear answers about how to treat abortion as a legal matter or that the ethical questions raised by unwanted pregnancies can be easily resolved. Strang discusses abortion in the context of the question of when courts should follow nonoriginalist precedents. A reader who fell from Mars and had no idea of the rigor and depths of the debate might find Strang's treatment of abortion measured and dispassionate. In fact, in this area, his scholarship veers into advocacy, as his one-sided footnotes (pp. 135-141) make clear.

First, Strang finds the evidence overwhelming that Roe is a non-originalist opinion, but that evidence draws on the original

73. See, e.g., Missouri v. Jenkins, 495 U.S. 33 (1990) (holding that a district court abused its discretion by sanctioning an increase in property tax to fund desegregation in Kansas City); Milliken v. Bradley, 418 U.S. 717 (1974) (blocking an inter-district solution to the problem of segregated schools in Detroit).

74. Parents Involved in Cmty. Schs. v. Seattle Sch. Dist. No. 1, 551 U.S. 701 (2007).

75. Id. at 746-47.

76. See id. at 733-34. 
expected application originalism that Strang rejects in other contexts (p. 136). Second, notwithstanding the Casey plurality opinion, ${ }^{77}$ which provided perhaps the most important Supreme Court discussion of when a precedent should be upheld because of reliance, ${ }^{78}$ Strang minimizes the reliance on the privacy right recognized in Roe and upheld in Casey. He notes, "[a] more traditional understanding of reliance would recognize that women who are pregnant (and those by whom they become pregnant) may have acted in reliance on Roe. There are relatively few such persons, and their reliance interests dissipate in the short term." (p. 138). This statement grossly understates the set of people who rely on constitutional guarantees of reproductive freedom, which encompass not only pregnant woman, but any woman who could become pregnant and any man who could impregnate a woman. I simply have no idea what Strang can mean when he claims that those people's interest in reproductive freedom dissipates in the short term. Does he imagine that a woman who cannot get a legal abortion simply shrugs and gets on with her life? Does he think the biological father of a child that his partner is forced to carry to term always walks away from his biological child without another thought? Or does he mean that reliance on the right recognized in Roe will fade once that case is overturned? The ongoing fight over abortion rights suggests otherwise.

Finally, Strang informs us that Roe is unjust (p. 138). He so concludes because he treats abortions as the deaths of unborn children (p. 138). I think it is important to take seriously the views of people who have concluded, on religious or ethical grounds, that abortion is murder. Nonetheless, there are at least two responses, neither of which Strang acknowledges. First, most Americans seem to think that abortion is not murder. According to the Pew Research Center on Religion and Public Life, $61 \%$ of Americans think that abortion should be legal in most or all cases. ${ }^{79}$ Second, the interest in the potential life of the fetus must be weighed against a woman's right to have control over her own body. Whether Roe effected justice or injustice turns on one's views on these arguments, and Strang does not engage them.

77. Planned Parenthood of Se. Pa. v. Casey, 505 U.S. 833 (1992).

78. See id. at 854-61.

79. Public Opinion on Abortion: Views on Abortion, 1995-2019, PEW RESEARCH CTR.: Religion \& PUB. LifE (Aug. 20, 2019), https://www.pewforum.org/fact-sheet /public-opinion-on-abortion/. 
Strang makes additional arguments that weaken his case. $\mathrm{He}$ claims that abortion breaks the "lives of women who aborted their children" (p. 138). In support of this statement, Strang provides citations to scholarship purporting to show the negative consequences of abortion for the women who choose to have them (pp. 138 n.462). Most scientists regard this scholarship as discredited based on fundamental flaws in methodology and logic, and because the reported results resist replication. ${ }^{80} \mathrm{He}$ alleges that Planned Parenthood, a non-profit organization, "profits from the fears of women who are pregnant in unfortunate circumstances" (pp. 138-139). In support of this claim, Strang cites Planned Parenthood's revenues (p. 139 n.463). ${ }^{81}$ Revenues are not profits.

Strang accuses Planned Parenthood of "targeting ... minority communities" (p. 139), without addressing studies that undermine that claim. ${ }^{82}$ In any case, according to its most recent annual report, the provision of STI testing and treatment, contraception, women's health services, and cancer screenings and prevention account for over $95 \%$ of Planned Parenthood's services, while abortion services account for $3.4 \%{ }^{83}$ If it were true that Planned Parenthood "targeted" minority neighborhoods, that would be laudable: a non-profit health services organization should target minority neighborhoods, whose populations have very high poverty rates and lack vital healthcare and other services. In short, there are arguments on both sides of the question of whether the Supreme Court did justice in finding that a constitutional right to privacy protects a woman's right to family planning services.

80. Showing the lack of scientific basis for each of the claims made in the studies that Strang cites goes beyond the scope of this review. To get a sense of the nature of the challenges to this literature, see, e.g., Gonzales v. Carhart, 550 U.S. 124, 183 n.7 (2007) (Ginsburg, J., dissenting); Study Purporting to Show Link Between Abortion and Mental Health Outcomes Decisively Debunked, GuTTMACHER InSTITUTE (Mar. 5, 2012), https://www.guttmacher.org/news-release/2012/study-purporting-show-link-betweenabortion-and-mental-health-outcomes-decisively.

81. Citing PlANNED PARENTHOOD, ANNUAL REPORT, 2015-2016, www.plannedparenthood.org/uploads/filer_public/18/40/1840b04b-55d3-4c00-959d11817023ffc8/20170526_annualreport_p02_singles.pdf.

82. See Amita Kelly, Fact Check: Was Planned Parenthood Started to "Control" the Black Population?, NPR: IT's AlL POLITICS (Aug. 14, 2015, 12:59 PM), https://www.npr.org/sections/itsallpolitics/2015/08/14/432080520/fact-check-was-plannedparenthood-started-to-control-the-black-population.

83. PlanNed PARENTHOOD, ANNUAL REPORT, 2017-2018, https://www.plannedparenthood.org/uploads/filer_public/4a/0f/4a0f3969-cf71-4ec3-8a90733c01ee8148/190124-annualreport18-p03.pdf, at 23. 
Strang's strained application of his method to the hot-button issues of abortion and school desegregation highlights how politics drives his theory. One could just as easily conclude that both Brown and Roe are originalist precedents or that both are non-originalist precedents but that rule of law interests favor the retention of both, because doing so would promote human flourishing and the common good. One could also conclude the opposite as to both cases or either case. When Strang incorporates "justice as fairness" into his analysis (pp. 130-133), the only thing that separates his approach from Ronald Dworkin's nonoriginalist moral reading of the Constitution ${ }^{84}$ is the opposition between Aristotelian and deontological approaches to ethics. In any case, Strang's claim that his version of originalism describes our constitutional tradition would be more convincing if it could account for the substantive due process and equal protection traditions that underlie constitutional protections of individual rights.

\section{ORIGINALIST NEO-SCHOLASTICISM AND THE CRISIS OF ORIGINALIST INTERPRETATION ${ }^{85}$}

In The Structure of Scientific Revolutions, ${ }^{86}$ Thomas Kuhn described scientists pursuing "normal science" 87 within an established paradigm. ${ }^{88}$ Eventually, scientists engaged in normal science stumble upon anomalies for which the paradigm gives no good account. ${ }^{89}$ Rather than abandoning the paradigm, scientists working within the paradigm modify it to address new phenomena. ${ }^{90}$ Eventually the modifications render the paradigm unwieldy or so unreliable that scientists cast about for a new one. Albert Einstein aptly described the emotional toll a paradigm shift can take on a scientist's psyche when he complained, "[i]t was as if the ground had been pulled out from under one, with no firm foundation to be seen anywhere, upon which one could have

84. Ronald Dworkin, Freedom's Law: The Moral Reading of THE AMERICAN CONSTITUTION (1996).

85. I am indebted to Ian Bartrum for prompting me to think about Thomas Kuhn's work in this context.

86. ThOMAS S. KuHN, THE STRUCTURE OF SCIENTIFIC REVOLUTIONS (2d ed. 1970).

87. Id. at $35-42$.

88. Id. at 176 .

89. Id. at 68 .

90. See id. at $75-77$. 
built." 91 The old paradigm becomes a hodgepodge that can explain the components of a body of knowledge, but when those components are assembled, they form not a recognizable body but a monster. ${ }^{92}$

Adherents of an old paradigm may dismiss new theories, partly out of devotion to a paradigm to which they have been professionally committed. ${ }^{93}$ The old paradigm may also offer ancillary benefits to which adherents owe a separate fealty, including membership in a community of scientists working in the same paradigm. For example, Aristotle's universe might seem preferable to Einstein's. While Einstein provides more elegant solutions to the problems of physics, Aristotle's comes with an invaluable metaphysical supplement. When one is forced to abandon a scientific paradigm, all of the scholarly works on which one has relied retain their value only to a historian of the discipline.

People operating in different paradigms will draw different conclusions from the same data. Originalists think that their theory captures the Framers' approach to constitutional interpretation, while I see non-hierarchical methodological pluralism and think that an originalist perspective on, for example, the jurisprudence of the Marshall Court distorts rather than describes its practice. Originalism, in Strang's hands, increasingly looks like a Kuhnian paradigm supplementing its core insights with complex and idiosyncratic revisions to address anomalies for which earlier iterations of the theory could not account. Strang's book embodies a paradigm on the verge of collapse.

Nobody could accuse Strang of a lack of sophistication. That sophistication has its costs. Strang's compromises among competing views and his intellectual complexity might render originalism unrecognizable to people drawn to the straightforward charm of the first generation originalists who insisted upon the simple idea that judges should be constrained by the Framers' original intentions. ${ }^{94}$ Eric Segall argues that, as

91. Id. at 83 (quoting Albert Einstein, Autobiographical Notes, in ALBERT EINSTEIN: PHILOSOPHER-SCIENTIST 45 (Paul Arthur Schilpp ed. 1949)).

92. See id. (citing ThOMAS S. KuHn, THE COPERNICAN REVOlution: Planetary ASTRONOMY IN THE DEVELOPMENT OF WESTERN THOUGHT 138 (1957)).

93. Id. at 64-65.

94. See Donald L. Drakeman, What's the Point of Originalism?, 37 HARV. J.L. \& 
originalism has moved away from the principle of deference to the political branches, it has become little more than a conservative version of legal realism. ${ }^{95}$ Strang rightly characterizes originalism as a family of interpretive theories. His approach attempts to settle conflicts within the family, but in so doing he renders the approach either anodyne or incoherent. No single member of the family can both describe and justify U.S. constitutional history, and the family taken together produces a cacophony in which everything can be explained by originalism and, at the same time, nothing is.

The distance between academic originalism and popular originalism is well illustrated in Section 4.4.3.3.5 (really!) of Strang's book, in which he provides nine reasons why one should not drive illegally on the shoulder of a highway to avoid a traffic jam (pp. 253-61). That erudite discussion is followed by Section 4.4.3.3.6, in which he provides four reasons why the legal authority that prohibits such behavior might be defeasible (pp. 261-65). All of that space devoted to giving reasons for the legitimacy of a legal rule whose reasonableness is beyond dispute does nothing to make the case for originalism. If one is inclined towards normative defenses of originalism, Strang's reasoning could be supplemented by deontological or consequentialist arguments, but the elaborate discussion of why one should abide clear and reasonable traffic rules does nothing to help us decide difficult cases of constitutional law. His general account of why one should follow the clear dictates of unambiguous legal norms does not help us determine how to go about determining the application of the Constitution's open-ended standards and principles.

Strang's attempt to link up his normative theory with originalism is also unpersuasive for the same reasons that his descriptive theory of originalism is unpersuasive. Strang's capacious originalism does not enable us to distinguish originalist precedents from non-originalist precedents. His attempts to limit the Constitution's indeterminacy similarly fail, because original methods originalism does not capture the Framers' approach to constitutional interpretation. The Framers' actual interpretive method-non-hierarchical interpretive pluralism-does not determine how constitutional standards and principles should be

PUB. POL'Y 1123, 1124-25 (2014).

95. SEGALL, supra note 3 , at 4 
applied to new cases but only provides us hermeneutic tools that judges could in good faith deploy in any number of ways.

Strang and other originalists might object that I am attempting to restrain originalism in a procrustean bed by refusing to acknowledge the breadth of originalist theory. A critic of originalism should not expect twenty-first-century originalists to limit themselves to the modes of argumentation available to Raoul Berger or Robert Bork. I would not want originalism to abandon sophistication in the hunt for methodological clarity. However, when a theory must constantly revise itself in order to address its own descriptive and normative failings, it may be time for a reset.

\section{THE EMERGING POST-ORIGINALIST PARADIGM}

One can accept every aspect of Strang's normative claim for originalism but reject his version of originalism based on three simple descriptive claims. First, the meaning of the Constitution's "majestic generalities," 96 which are the subject of the vast majority of constitutional disputes, is indeterminate. Second, that indeterminacy was intentional - the Framers agreed to disagree and to adopt broad language for future generations to adapt to future needs. Third, as Strang notes, the United States of today is nothing like the society that gave us our Constitution (pp. 206208). On occasion, rules imagined for a small eighteenth-century polity make no sense for the most powerful state the world has ever known. As a result, we treat, and we have always treated, the Constitution as guiding our action but not always binding our hands. In 1789, George Washington had a fit, and so the Senate's power to "advise and consent" 97 to treaties was reduced to a power to consent. ${ }^{98}$ The Framers envisioned no federal standing army, no cabinet, no parties, and dozens of other structures that Keith Whittington has characterized as the products of constitutional construction. ${ }^{99}$ In the postbellum era, we

96. W. Va. State Bd. of Educ. v. Barnette, 319 U.S. 624, 639 (1943).

97. U.S. CONST. art. II, § 2, cl. 2.

98. The incident is recounted in 1 DAVID M. KENNEDY \& THOMAS A. BAILEY, THE AMERICAN SPIRIT: UNITED STATES History AS SEEN By CONTEMPORARIES, 205-06 (12th ed. 2009); see also Curtis A. Bradley \& Martin S. Flaherty, Executive Power Essentialism and Foreign Affairs, 102 MICH. L. REV. 545, 631, 634 (2004).

99. KeIth E. Whittington, CONSTITUtional CONSTRUCtion: Divided Powers And Constitutional Meaning 12 (1999); see also Gordon S. Wood, The Fundamentalists and the Constitution, N.Y. REV. BOoKs (Feb. 18, 1988), 
established the legal basis for the administrative state, ${ }^{100}$ which bore fruit during the New Deal, when we reduced the nondelegation doctrine to a mere whisper of its earlier potency. ${ }^{101}$ The result is a complete transformation of the way in which U.S. law is promulgated and executed.

The first two descriptive claims give rise to a merger of originalism and non-originalism that Jack Balkin has dubbed "living originalism." If the Framers intended for us to adapt the Constitution's general principles to suit contemporary purposes, the difference between originalism and living constitutionalism evaporates. Strang's approach attempts to reduce constitutional indeterminacy to a point where decisionmakers endowed with virtue ethics can be entrusted to apply their practical wisdom and reach just conclusions. It may be that indeterminacy is not only a part of the constitutional design but the intended engine of our democratic processes. Those processes continue today, and works such as Strang's enrich our conversations about the meaning of the Constitution that animates our collective political life.

https://www.nybooks.com/articles/1988/02/18/the-fundamentalists-and-the-constitution/ (noting that the cabinet, administrative agencies, political parties, and judicial review are "unmentioned in the Constitution and are the products of historical experience").

100. See Laura Kalman, Legal Realism At Yale 1927-1960, at 3 (1986) (describing administrative law as an embryonic practice area of federal law before the New Deal).

101. See Lisa Schultz Bressman, Schechter Poultry at the Millennium: A Delegation Doctrine for the Administrative State, 109 YALE L.J. 1399, 1401 (2000) (noting that the Supreme Court has not expressly relied on the non-delegation doctrine to strike down a statute since 1935); Gary Lawson, The Rise and Rise of the Administrative State, 107 HARV. L. REV 1231, 1237-41 (1994) (decrying the "[d]eath of the [n]ondelegation [d]octrine"). 
